\title{
FAKTOR- FAKTOR YANG MEMPENGARUHI ADOPSI TEKNOLOGI BUDIDAYA TANAMAN PADI SAWAH DI KECAMATAN KUPANG TIMUR KABUPATEN KUPANG PROPINSI NUSA TENGGARA TIMUR
}

\author{
Wely Yitro Pello dan Cokorda B. D. P. Mahardika
}

Jurusan Manajemen Pertanian Lahan Kering, Politeknik Pertanian Negeri Kupang, J. Prof. Dr. Herman Yohanes Lasiana Kupang P.O.Box. 1152, Kupang 85011

Korespondensi: welypello985@gmail.com

\begin{abstract}
This research aimed to find out how lowland rice farming technology is being adopted in East Kupang District (Y), as well as the impact of internal (X1) and external (X2) factors (Y). Multiple linear regression is used to analyze data. The study's findings revealed that Rice Field Cultivation Technology Adoption was High Criteria (74.36\%), and Hypothesis Testing compared the t-count and t-table values (2.039) at a significant threshold of 0.05. The results demonstrate that Extension Quality (X2.2) has an external factor (X2) of 2.067, and Farmer Participation in Farmer Groups (X2.3) has an external factor (X2.3) of 4.080, both of which have an effect on $Y$.
\end{abstract}

Keywords : Paddy Rice, Adoption, and Cultivation

\section{PENDAHULUAN}

Salah satu bahan eksport pertanian yang terus ditingkatkan adalah tanaman padi dimana Kementerian Pertanian menargetkan tahun 2015 sampai 2019 produksi padi mencapai angka 80,08 juta ton (Renstra Kementan 2015-2019). Untuk mecapai target tersebut diharapkan semua daerah turut berperan dalam mendukung tercapainya produksi yang ditargetkan.

Salah satu daerah yang perlu mendukung ketersediaan tujuh komoditas unggulan (Padi, Jagung, Tebu, Kedelai, Cabai, Bawang Merah, dan Daging Sapi) adalah Provinsi Nusa Tenggara Timur (NTT), salah satu komoditas unggul yang dibudidayakan di NTT adalah tanaman padi. Badan Pusat Statistik (2016) mencatat bahwa jumlah produksi tanaman padi di NTT mencapai 948,988 ton GKG, sedangkan angka tetap pada tahun 2014 sebanyak 1,299,845 ton GKG baik padi sawah maupun padi ladang, hal ini menunjukan bahwa terdapat penurunan produksi hasil panen padi sebanyak 37,10 persen. Dari beberapa kabupaten yang mengalami penurunan produksi salah satunya adalah Kabupaten Kupang dimana dari data BPS (2016) terjadi penurunan produksi di tahun 2015 hasil 
produksi padi sebanyak 73,234 ton sedangkan di tahun 2014 hasil panen mencapai 91,136 ton atau terdapat penurunan sebesar 24.44 persen. Dari beberapa kecamatan salah satu yang menunjukan penurunan produksi cukup tinggi adalah Kecamatan Kupanng Timur yaitu tahun 2015 hasil produksi padi sebanyak 12,911 ton GKG sedangkan ditahun 2014 hasil produksi padi sebanyak 17,082.9 ton GKG. Hal ini diduga disebabkan karena iklim yang kering, belum optimalnya penyuluh dalam meningkatkan teknik dan intensifikasi budidaya tanaman padi misalnya PTT, SRI, dan sistem Legowo, belum optimalisasi pemanfaatan lahan tidur dan pembukaan lahan sawah baru sehingga munculnya pengalihan lahan sawah dengan tanaman lain. BPS (2016) mencatat bahwa pengalihan lahan sawah di NTT cukup besar yaitu sebanyak 33,536 ha meliputi luas lahan sawah yang ditanami tanaman lainnya sebesar 9,191 ha dan 24,345 ha tidak ditanami apapun.

Hal inilah yang perlu adanya pendekatan dari pemerintah dalam hal ini melalui optimalisasi peran penyuluh guna membantu petani dengan meningkatkan teknik dan intensifikasi budidaya tanaman padi misalnya PTT, SRI, dan sistem Legowo sehingga adanya peningkatan produksi padi sawah yang berakibat pada menurunnya pengalihan lahan sawah tersebut. Salah satu teknik budidaya tanaman padi dengan menggunakan teknik SRI (System of Rice Intensification) telah dikembangkan di Desa Tarus, Kecamatan Kupang Tengah, Kabupaten Kupang, NTT, dimana mampu meningkatkan hasil panen hingga 100 persen dari bibit padi yang biasa digunakan dengan kebutuhan air yang sedikit.

Hasil ini menunjukan bahwa dengan penerapan teknik dan intensifikasi budidaya tanaman padi yang baik dan adanya dukungan peran penyuluh akan mampu meningkatkan hasil produktifitas tanaman padi. Dari hasil penelitian Pello, dkk (2018) dan hasil penelitian Pello, dkk (2019) di Kecamatan Kupang Timur menunjukan bahwa Tingkat Penerapan Teknologi Padi Sawah berada pada kategori Tinggi dengan persentasi 58.34\% - 74.50\%, sehingga hasil ini perlu di kaji lebih lanjut untuk mengidentifikasi faktor-faktor yang mempengaruhi tingkat adopsi teknologi padi sawah di kecamatan Kupang Timur. 


\section{METODE PENELITIAN}

Daerah penelitian ditentuan secara purposive pada Kelompok Tani Padi Sawah di Kecamatan Kupang Timur. Menurut Sugiyono (2010) sampling purposive adala teknik penentuan sampel dengan pertimbangan tertentu, yang artinya bahwa setiap subyek yang diambil dari populasi dipilih dengan secara sengaja berdasarkan tujuan dan pertimbangan tertentu.

\section{Penentuan Lokasi dan Waktu Penelitian}

Daerah penelitian ditentuan secara purposive pada Kelompok Tani Padi Sawah di Kecamatan Kupang Timur. Menurut Sugiyono (2010) sampling purposive adala teknik penentuan sampel dengan pertimbangan tertentu, yang artinya bahwa setiap subyek yang diambil dari populasi dipilih dengan secara sengaja berdasarkan tujuan dan pertimbangan tertentu. Penelitian dilakukan pada bulan Maret sampai bulan Oktober tahun 2019. Pemilihan lokasi dilakukan secara sengaja (purposive), dengan pertimbangan bahwa kabupaten tersebut merupakan daerah dengan area persawahan yang luas Provinsi NTT.

\section{Jenis dan Sumber Data}

Data primer bersumber dari petani Padi Sawah dan Penyuluh Pertanian di Kecamatan Kupang Timur. Pengambilan Data menggunakan Kuesioner dan FGD.

\section{Metode Pengumpulan Data}

Jenis penelitian yang digunakan adalah ex post facto, yaitu bentuk penelitian yang menilai peristiwa yang telah terjadi atau penilaian kondisi faktual di lapangan. Peubah-peubah penelitian meliputi peubah bebas (X) dan peubah terikat (Y). Peubah bebas (X), terdiri dari: Faktor Internal dan Faktor Eksternal. Peubah terikat (Y) Yaitu Adopsi Teknologi Budidaya Padi di Kecamatan Kupang Timur. Pengumpulan data dilakukan menggunakan Focus Group Discussion dan Penyebaran Kuesioner dengan mengajukan pertanyaan terbuka kepada 40 responden yang merupakan anggota kelompok tani padi sawah dengan

\section{Teknik Analisis Data}

Analisis data menggunakan Regresi Linear Berganda. 


\section{HASIL DAN PEMBAHASAN}

Analisis Tingkat Adopsi Teknologi Budidaya Tanaman Padi Sawah di Kecamatan Kupang Timur. Adapun indikator penilaian adopsi teknologi budidaya tanaman padi sawah meliputi ; Jarak Tanam, Penggunaan Bibit Unggul, Pengolahan Lahan, Pemupukan, Pengairan, Pengendalian OPT, dan Penggunaan Pestidida Alami. Responden memberikan penilaian sebesar 89,13\% terhadap sub variabel Adopsi Teknologi Budidaya Tanaman Padi Sawah. Deskripsi data penelitian Adopsi Teknologi budidaya tanaman padi sawah $(\mathrm{Y})$ tersaji pada gambar 1. Pada gambar tersebut dapat dilihat bahwa responden lebih banyak memberikan penilaian terhadap variabel adopsi teknologi budidaya tanaman padi sawah pada kriteria tinggi yaitu sebanyak 29 Orang atau sebesar 74,36\%.

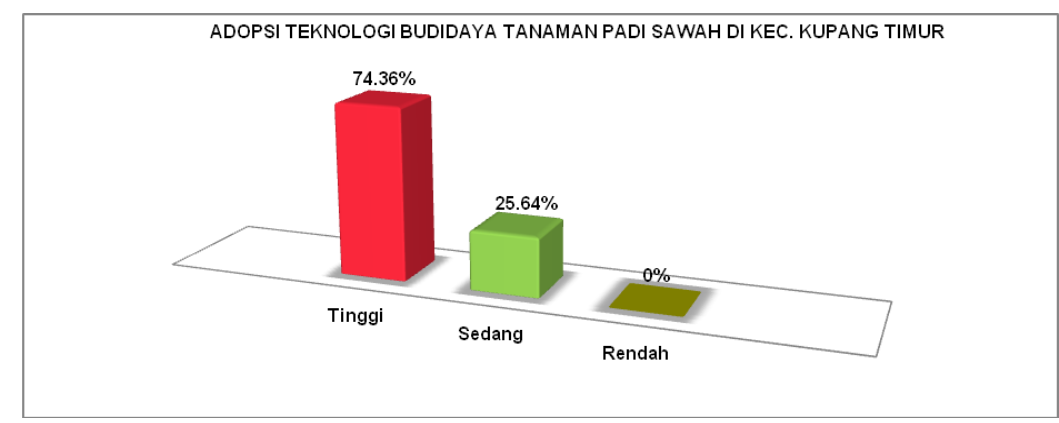

Gambar 1. Grafik Adopsi Teknologi Budidaya Tanaman Padi Sawah

Adapun perincian berdasarkan pada tabel berikut:

Tabel 1. Penilaian responden pada masing-masing pernyataan

\begin{tabular}{llccc}
\hline No & \multicolumn{1}{c}{ PERNYATAAN } & $\begin{array}{c}\text { Interval } \\
\text { Skor }\end{array}$ & $\begin{array}{c}\text { Skor } \\
\text { Capaian }\end{array}$ & $\begin{array}{c}\text { Persentasi } \\
\text { Capaian }\end{array}$ \\
\hline & Adopsi Teknologi Budidaya Tanaman Padi Sawah & $1-15$ & 16.10 & 89.13 \\
\hline $\begin{array}{l}\text { Petani menerapkan jarak tanam pada tanaman padi } \\
\text { dengan baik dan benar sesuai dengan yang disampaikan } \\
\text { oleh penyuluh pendamping }\end{array}$ & $1-3$ & 2.69 & 89.74 \\
\hline $2 \quad \begin{array}{l}\text { Petani menggunakan bibit unggul dalam budidaya } \\
\text { tanaman padi sawah }\end{array}$ & $1-3$ & 2.72 & 90.60 \\
\hline 3 & $\begin{array}{l}\text { Petani melakukan pengolahan tanah yang baik dengan } \\
\text { penggunakan teknologi pertanian sesuai dengan anjuran } \\
\text { penyluh pendamping }\end{array}$ & $1-3$ & 2.87 \\
\hline
\end{tabular}




\begin{tabular}{|c|c|c|c|c|}
\hline No & PERNYATAAN & $\begin{array}{l}\text { Interval } \\
\text { Skor }\end{array}$ & $\begin{array}{c}\text { Skor } \\
\text { Capaian }\end{array}$ & $\begin{array}{c}\text { Persentasi } \\
\text { Capaian }\end{array}$ \\
\hline 4 & $\begin{array}{l}\text { Petani melakukan pemupukan dengan cara dan dosis yang } \\
\text { tepat sesuai dengan anjuran penyuluh pendamping }\end{array}$ & $1-3$ & 2.95 & 98.29 \\
\hline 5 & $\begin{array}{l}\text { Petani melakukan pengairan pada tanaman padi sawah } \\
\text { dengan sistem yang baik }\end{array}$ & $1-3$ & 2.49 & 82.91 \\
\hline 6 & $\begin{array}{l}\text { Petani mengetahui dan melakukan cara pengendalian } \\
\text { organisme pengganggu tanaman sesuai anjuran penyuluh }\end{array}$ & $1-3$ & 2.39 & 79.49 \\
\hline 7 & $\begin{array}{l}\text { Petani mengikuti penyuluhan tentang pestisida alami yang } \\
\text { ramah lingkungan dan menerapkan pada budidaya } \\
\text { tanaman padi }\end{array}$ & $1-3$ & 2.62 & 87.13 \\
\hline
\end{tabular}

Berdasarkan hasil analisis pada Gambar 1 di atas menunjukkan bahwa sebagian besar responden cenderung memberikan penilaian pada kriteria tinggi terhadap setiap pernyataan yang diberikan. Pemberian nilai pada kriteria tinggi disebabkan oleh karena petani telah melakukan adopsi teknologi budidaya tanaman padi sawah sesuai dengan informasi yang telah diterima melalui kegiatan penyuluhan yang disampaikan oleh penyuluh pendamping.

\section{Faktor Internal dan Fakor Eksternal Adopsi Teknologi Budidaya Tanaman Padi Sawah}

Berdasarkan data penelitian yang telah dikumpulkan, diperoleh data penilaian responden terhadap Fator Internal dan Faktor Eksternal $\left(\mathrm{X}_{1}\right.$ dan $\left.\mathrm{X}_{2}\right)$. Adapun indikator faktor internal dan faktor eksternal yag menjadi faktor pendukung adopsi teknologi budidaya tanaman padi sawah oleh petani padi di Kecamatan Kupang Timur adalah $\mathrm{X}_{1}$ : Pengalaman Berusahatani, Status Kepemilikan Lahan, Tingkat Pendapatan, Kosmopolitan, Ketersediaan Modal. $\mathrm{X}_{2}$ : Peran Penyuluh Pertanian, Kualitas Penyuluhan, dan Partisipasi Dalam Kelompok Tani. Data penelitian variabel Faktor Internal dan Faktor Eksternal $\left(\mathrm{X}_{1}\right.$ dan $\left.\mathrm{X}_{2}\right)$ tersaji pada Tabel berikut; 
Tabel 2. Distribusi Responden Berdasarkan Faktor Internal dalam Adopsi Teknologi Padi Sawah

\begin{tabular}{|c|c|c|c|c|}
\hline No & Kriteria & Skor & Jumlah Responden (Org) & Persentase (\%) \\
\hline \multicolumn{5}{|c|}{ Pengalaman Berusahatani $\left(X_{1.1}\right)$} \\
\hline 1 & Rendah & 1 & 0 & 0 \\
\hline 2 & Sedang & 2 & 9 & 23.08 \\
\hline 3 & Tinggi & 3 & 30 & 76.92 \\
\hline \multicolumn{5}{|c|}{ Status Kepemilikan Lahan $\left(X_{1.2}\right)$} \\
\hline 1 & Rendah & 1 & 7 & 17.95 \\
\hline 2 & Sedang & 2 & 28 & 71.79 \\
\hline 3 & Tinggi & 3 & 4 & 10.26 \\
\hline \multicolumn{5}{|c|}{ Tingkat Pendapatan $\left(X_{1.3}\right)$} \\
\hline 1 & Rendah & 1 & 2 & 5.13 \\
\hline 2 & Sedang & 2 & 37 & 94.87 \\
\hline 3 & Tinggi & 3 & 0 & 0 \\
\hline \multicolumn{5}{|c|}{ Kosmopolitan $\left(X_{1.4}\right)$} \\
\hline 1 & Rendah & 1 & 7 & 17.95 \\
\hline 2 & Sedang & 2 & 29 & 74.36 \\
\hline 3 & Tinggi & 3 & 3 & 7.69 \\
\hline \multicolumn{5}{|c|}{ Ketersediaan Modal $\left(X_{1.5}\right)$} \\
\hline 1 & Rendah & 1 & 0 & 0 \\
\hline 2 & Sedang & 2 & 13 & 33.33 \\
\hline 3 & Tinggi & 3 & 26 & 66.67 \\
\hline
\end{tabular}

Berdasarkan pada tabel 2. diketahui bahwa ada 5 faktor internal yang terdapat dalam adopsi teknologi budidaya tanaman padi sawah, yaitu pengalaman berusahatani, status kepemilikan lahan, tingkat pendapatan, kekosmopolitan, dan ketersediaan modal. Dari ke 5 faktor tersebut diketahui bahwa ada 2 faktor yang diberikan penilaian oleh responden pada kriteria tinggi adalah faktor pengalaman berusahatani dan ketersediaan modal. Petani padi sawah di kecamatan Kupang Timur rata-rata memiliki pengalaman berusahatani sudah di atas 10 tahun atau dengan kata lain petani responden merupakan petani yang sangat berpengalaman dalam menjalankan usahatani khususnya dalam budidaya tanaman padi sawah, sejalan dengan hal tersebut diketahui juga bahwa ketersediaan modal merupakan faktor penting yang mendukung terjadinya proses adopsi suatu teknologi oleh petani. Keteresdiaan modal yang dimiliki leh petani padi sawah di kecamatan kupang timu secara mandiri/swadaya mulai dari persiapan lahan sampai panen. Sedangkan status kepemilikan lahan, tingkat pendapatan, dan kekosmopolitan, petani memberikan penilaian pada kriteria sedang. Untuk status kepemilikan lahan yang dimiliki oleh petani padi di kecamatan kupang timur mulai dari milik sendiri, garap/sistem bagi hasil dan 
sistem kontrak. Tingkat pendapatan petani dari budidaya tanaman padi sawah juga berada pada kriteria sedang dimana pendapatan petani dari budidaya tanaman padi dapat memenuhi kebutuhan utama (makan) dan untuk membiayai sekolah anak.

Tabel 3. Distribusi Responden Berdasarkan Faktor Eksternal dalam Adopsi Teknologi Padi Sawah

\begin{tabular}{llccc}
\hline No & Kriteria & Skor & Jumlah Responden (Org) & $\begin{array}{c}\text { Persentase } \\
\text { (\%) }\end{array}$ \\
\hline Peran Penyuluh $\left(X_{2.1}\right)$ & & & \\
\hline 1 & Rendah & 1 & 5 & 5.13 \\
\hline 2 & Sedang & 2 & 32 & 12.82 \\
\hline 3 & Tinggi & 3 & & 82.05 \\
\hline Kualitas Penyuluhan $\left(X_{2.2}\right)$ & & 4 & 10.26 \\
\hline 1 & Rendah & 1 & 23 & 58.97 \\
\hline 2 & Sedang & 2 & 12 & 30.77 \\
\hline 3 & Tinggi & 3 & & 0 \\
\hline Partisipasi Petani Dalam Kelompok Tani & $\left(X_{2.3}\right)$ & 0 & 46.15 \\
\hline 1 & Rendah & 1 & 18 & 53.84 \\
\hline 2 & Sedang & 2 & 21 & \\
\hline 3 & Tinggi & 3 &
\end{tabular}

Pada Tabel 3 diketahui bahwa terdapat 3 faktor eksternal dalam adopsi teknologi budidaya tanaman padi sawah. Faktor peran penyuluh merupakan faktor yang diberikan penilaian pada kriteria tinggi oleh patani, peran penyuluh dalam mendampingi petani baik sebagai fasilitator maupun motivator sangat baik dan dirasakan oleh petani dalam menjalankan usahatani padi sawah dimana peani dalam menjalan panca usahatani khusunya dalam budidaya selalu didampingi oleh petani, sedangkan kulaitas penyuluh dan partisipasi petani dalam kelompok tani berada pada kategori sedang. Kualitas penyuluhan yang dinilai sedang karena setiap materi yang diberikan oleh penyuluh sudah sesuai dengan kebutuhan petani sebagai informasi dan pengetahun dalam berusahatani sedangkan bnetuk partisipasi yang dilakukan oleh petani adalah memberikan sumbangan tenaga, pikiran, waktu dan biaya bagi pengembnagan kelompok tani dan dilakukan sebagai bentuk tanggungjawab oleh semua anggota kelompok tani di kecamatan Kupang Timur. 


\section{Pengaruh Secara Parsial Faktor Internal dan Faktor Eksternal Terhadap Adopsi Teknologi Budidaya Tanaman Padi Sawah}

Tabel 4. Hasil Uji Pengaruh Secara Parsial Faktor Internal dan Faktor Eksternal Terhadap Adopsi Teknologi Budidaya Tanaman Padi Sawah

\begin{tabular}{lcccc}
\hline \multicolumn{1}{c}{ Uraian } & $\boldsymbol{\beta}$ & $\mathbf{t}$ hitung & Sign & Keterangan \\
\hline (Constant) & 17,209 & 5,026 & 0,000 & Tidak Signifikan \\
\hline Pengalaman Berusahatani & $-0,196$ & $-0,929$ & 0,360 & Tidak Signifikan \\
\hline Status Kepemilikan Lahan & $-0,081$ & $-0,398$ & 0,693 & Tidak Signifikan \\
\hline Tingkat Pendapatan & $-0,030$ & $-0,284$ & 0,778 & Tidak Signifikan \\
\hline Kekosmopolitan & $-0,072$ & $-0,375$ & 0,068 & Tidak Signifikan \\
\hline Ketersediaan Modal & $-0,072$ & $-0,074$ & 0,575 & Tidak Signifikan \\
\hline Peran Penyuluh & 0,070 & 0,304 & 0,763 & Tidak Signifikan \\
\hline Kualitas Penyuluhan & & & & \\
\hline Partisipasi Petani Dalam Kelompok Tani & 0,485 & 4,080 & 0,000 & Sangat Signifikan \\
\hline
\end{tabular}

Berdasarkan hasil analisis pada Tabel 4 di atas menunjukkan bahwa terdapat pengaruh yang signifikant faktor eksternal (Kualitas Penyuluhan dan Partisipasi Anggota Kelompok Tani) terhadap adopsi teknologi budidaya tanaman padi sawah di Keamatan Kupang Timur, hal ini menunjukkan bahwa semakin baik kualitas penyuluhan dan semakin tinggi partisipasi anggota kelompok tani dalam kelompok maka akan dapat meningkatkan tingkat adopsi teknologi budidaya tanaman padi sawah.

\section{Pengaruh Kualitas Penyuluhan Terhadap Adopsi Teknologi Budidaya Tanaman Padi Sawah}

Pada Tabel 4 menunjukkan bahwa kualitas penyuluhan berpengaruh terhadap adopsi teknologi budidaya tanaman padi sawah. Artinya bahwa setiap peningkatan kualitas penyuluhan seperti penyampaian materi penyuluhan, intensitas kegiatan penyuluhan, metode penyuluhan dan media atau media bantu penyuluhan memiliki dampak yang positif terhadap peningkatan penerapan teknologi budidaya tanaman padi sawah. Hal ini disebabkan karena rata-rata 
$58,97 \%$ (Tabel 3) responden mengatakan bahwa materi penyuluhan yang disampaikan berkualitas dan intensitas kegiatan penyuluhan sesuai dengan kebutuhan petani dalam budidaya tanaman padi sawah serta dapat memberikan solusi bagi permasalahan yang dihadapi oleh petani. Hal ini sejalan dengan pendapat Mardikanto (2014) bahwa sifat materi penyuluhan yang berkualitas adalah materi yang penyuluhan yang berisikan pemecahan masalah yang sedang dan akan dihadapi oleh petani, berisikan petunjuk dan rekomendasi yang harus dilakukan oleh petani (sesuai kebutuhan) serta materi yang bersifat instrumental (materi yang tidak harus dikonsumsi dalam waktu cepat tetapi yang memiliki manfaat jangka panjang.

\section{Pengaruh Partisipasi Petani Dalam Kelompok Tani Terhadap Adopsi Teknologi Budidaya Tanaman Padi Sawah}

Partisipasi merupakan keterlibatan atau keikutsertaan dalam suatu kegiatan dan dapat bersama-sama belajar serta menerapkan teknologi baru bagi petani. Semakin tinggi partisipasi petani dalam kelompok tani yang merupakan media belajar bersama bagi para petani maka semakin tinggi tingkat adopsi petani terhadap teknologi budidaya tanaman padi sawah. Hal ini disebabkan karena rata-rata 53,84\% (Tabel 3) responden memberikan jawaban pada kriteria tinggi bahwa petani melakukan partisipasi dalam kelompok tani dengan tujuan sebagai bentuk kebersaman berbagi pengalaman untuk pengembangan diri dan usahatani. Hal tersebut sesuai dengan pendapat Mardikanto (2014) bahwa Keberhasil penyuluhan dan percepatan adopsi teknologi tida diukur dari dari seberapa banyak terjadi alih pengetahuan, tetapi seberapa jauh terjadi interaksi atau diskusi dan berbagi pengalaman (sharing) antara sesama peserta maupun fasilitator dan pesertanya.

\section{SIMPULAN}

Berdasarkan hasil penelitian dan pembahasan, maka dapat disimpulkan bahwa;

1. Tingkat Adopsi Teknologi Budidaya Tanaman Padi Sawah di Kecamatan Kupang Timur (Y) berada pada Kriteria Tinggi (74,36\%).

2. Faktor Internal dan Faktor Eksternal yang Berpengaruh Terhadap Adopsi 
Teknologi Budidaya Tanaman Padi Sawah di Kecamatan Kupang Timur adalah Faktor Kualitas Penyuluhan $\left(\mathrm{X}_{2.2)}\right.$ dan Faktor Partisipasi Petani dalam Kelompok Tani $\left(\mathrm{X}_{2.3}\right)$ dimana Nilai signifikan Faktor Kualitas Penyuluhan adalah 0,047 dan nilai signifikan faktor Partisipasi Petani dalam Kelompok Tani Terhadap Adopsi Teknologi Budidaya Tanaman Padi Sawah (Y) adalah 0,000.

Kedua faktor yang berpengaruh terhadap Adopsi Teknologi Budidaya Tanaman Padi Sawah di Kecamatan Kupang Timur merupak faktor eksternal atau faktor yang datang dari luar diri petani.

\section{DAFTAR PUSTAKA}

Arikunto, S. 2006. Metode Penelitian Kualitatif. Jakarta : Bumi Aksara.

BPS. Kabupaten Kupang. 2016. Kabupaten Kupang Dalam Angka 2016.

BPS. Propinsi NTT. 2016. Propinsi Nusa Tenggara Timur Dalam Angka 2016.

Mardikanto, T. 2014. Sistem Penyuluhan Pertanian. Sebelas Maret University Press. Surakarta.

Sugiyono, 2010. Metode Penelitian Pendidikan Pendekatan Kuantitatif, Kualitatif, dan $R \& D$. Bandung : Alfabeta.

Pello, W. Y. Banunaek, M.F. 2019. Pengaruh Peran Penyuluh dan Motivasi Penyuluh Pertanian Terhadap Inovasi Teknologi Budidaya Tanaman Padi Sawah di Kecamatan Kupang Timur, Kabupaten Kupang, NTT. Jurnal Penyuluhan IPB. Edisi September 2019. Vol. 15 Nomor 2. 